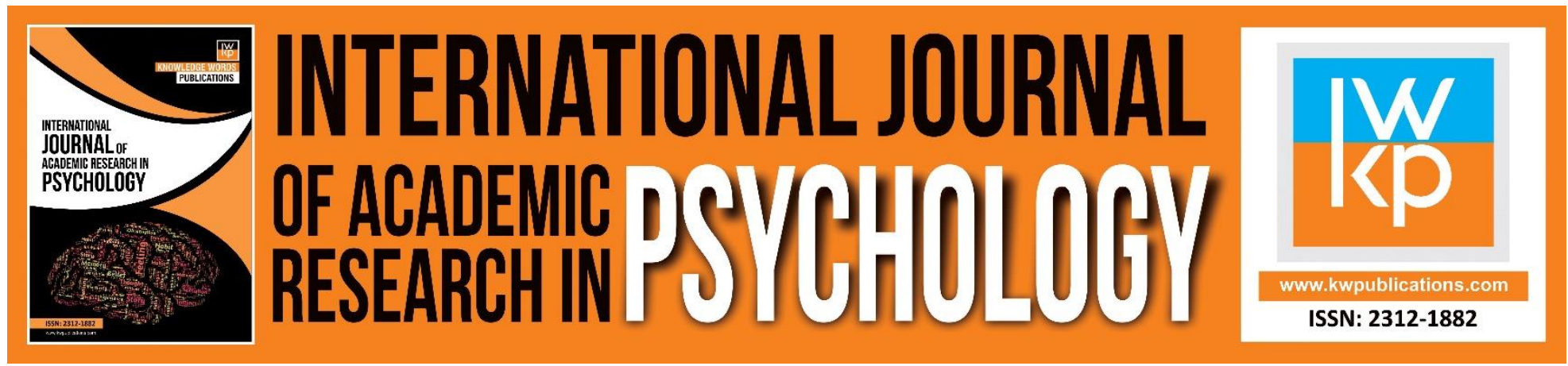

\title{
Knowledge on HIV/AIDS and Condom Practices (Sexual High- Risk Behaviour) among Young Transgender: A Case Study in Southern Thailand
}

\author{
Kumarashwaran Vadevelu, Wanapat Sangkaew, Varunya Temrat, Natsarin \\ Saesa, Thanidaphat Saengtong, Suwara Kaewnuy
}

To Link this Article: http://dx.doi.org/10.46886/IJARP/v7-i1/7230

DOI:10.46886/IJARP/v7-i1/7230

Received: 02 March 2020, Revised: 27 April 2020, Accepted: 16 May 2020

Published Online: 26 May 2020

In-Text Citation: (Vadevelu et. al., 2020)

To Cite this Article: Vadevelu, K., Sangkaew, W., Temrat, V., Saesa, N., Saengtong, T., \& Suwara Kaewnuy. (2020). Knowledge on HIV/AIDS and Condom Practices (Sexual High-Risk Behaviour) among Young Transgender: A Case Study in Southern Thailand. International Journal of Academic Research in Psychology, 7(1), 37-45.

Copyright: (c) 2020 The Author(s)

Published by Knowledge Words Publications (www.kwpublications.com)

This article is published under the Creative Commons Attribution (CC BY 4.0) license. Anyone may reproduce, distribute, translate and create derivative works of this article (for both commercial and non-commercial purposes), subject to full attribution to the original publication and authors. The full terms of this license may be seen at: http://creativecommons.org/licences/by/4.0/legalcode

Vol. 7, No. 1, 2020, Pg. 37 - 45

https://kwpublications.com/journals/journaldetail/IJARP

JOURNAL HOMEPAGE

Full Terms \& Conditions of access and use can be found at https://kwpublications.com/pages/detail/publication-ethics 


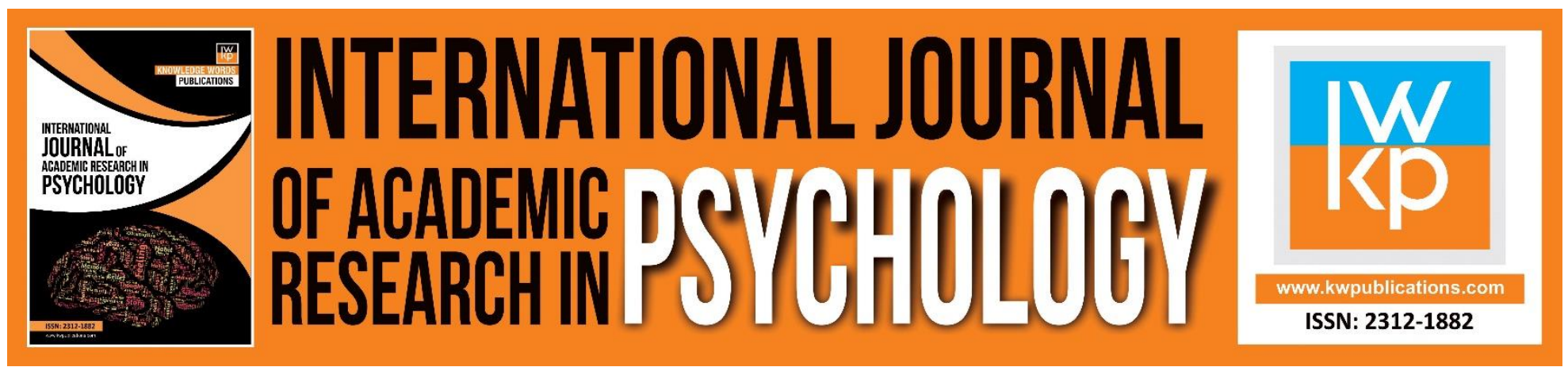

\title{
Knowledge on HIV/AIDS and Condom Practices (Sexual High-Risk Behaviour) Among Young Transgender: A Case Study in Southern Thailand
}

\section{Kumarashwaran Vadevelu, Wanapat Sangkaew, Varunya Temrat, Natsarin Saesa, Thanidaphat Saengtong, Suwara Kaewnuy}

Faculty of Humanities and Social Sciences, Social Work Section, Prince of Songkla University, Pattani

Thailand

Email: kumarashwaran@yahoo.com

\begin{abstract}
The objective of this study is to qualitatively describe the ineffective condom practice rates, sexual high-risk ratio, and HIV/AIDS prevalence among the transgender population in Southern Thailand (Pattani, Yala, and Narathiwat provinces). The snowballing sampling method was employed to select 30 transgender respondents, and the semi-structured face-to-face interview sessions were held to gather data. As a result, although most of the respondents were aware of the dangers posed by HIV/AIDS, they were uncertain about the transmission of HIV virus. Additionally, most of the respondents failed to get tested in order to determine their HIV/AIDS status. Another rising concern is that a majority of the respondents were unaware of the significance of safe sex using condoms. Hence, supporting bodies should disperse awareness pertaining to effective use of condoms and the importance of safe sex in combatting HIV/AIDS.
\end{abstract}

Keywords: Transgender Youth, Transgender Transition, Social Support System.

\section{Introduction}

Countries are progressively recognising the significance of preparing youthful individuals with information and abilities to create capable choices in their lives, especially in a setting where they have more prominent introduction to sexually unequivocal material via internet and other platforms. The 2030 Agenda and its global Sustainable Development Goals call for action to leave no one behind, including the realisation of social justice and gender equality for all (UN, 2015).

Surveillance data on HIV prevalence among transgender individuals have not been systematically collected. Based on some surveys, the transgender populations are reported to have some of the highest HIV prevalence rates in the region, ranging from 8.7\% in Phnom Penh (2005), to 22\% in Jakarta (2002), 29\% in Myanmar, and 31\% in Bangkok (2007) (Chemnasiri et al., 2010). Young people within 10-24 age range appeared to constitute one-quarter of the world's population (UN, 
2012) and they are among those most affected by the global epidemic of human immunodeficiency virus (HIV). In 2013, about 5 million people aged 10-24 years old were living with HIV, and those within 15-24 age range accounted for an estimated $35 \%$ of all new infections worldwide (UN, 2013).

Approximately 75,626 transgender women in Thailand participated in a programme that investigated an HIV/AIDS strategic planning. The rigorous estimation is planned and will be updated in the near future. A significant fraction of the transgender population is concentrated in major cities. The immediate HIV risk amongst young transgender people has been linked to sexual behaviours, especially unprotected anal sex with an HIV positive partner, as well as other structural factors that make young transgender people especially vulnerable to HIV (WHO, 2014). Transgender persons and men having sex with men (MSM) are at an increased risk of HIV infection if they have unprotected penetrative sex. In 2005, 46.7\% of MSM, 34.9\% of men having sex with women (MSW), and $52.3 \%$ of transgender women sampled in Bangkok, Chiang Mai, and Phuket reported inconsistent condom usage (Chemnasiri et al., 2010).

The high cost of transition healthcare adds more pressure on the transgender group to generate cash. Since sex workers tend to get paid more for unprotected sex, they become more vulnerable to HIV (APTN/UNDP, 2012). In numerous settings, youthful key populaces have continued to bear unbalanced burdens of HIV counting youthful gays, MSM, and transgender youth (Bekker et al., 2015

\section{Study Objective and Methodology}

The objectives of this study are

- To qualitatively describe the ineffective condom practice rates among young transgender,

- To explore the level of sexual high-risk ratio towards HIV/AIDS prevalence among the transgender population in Southern Thailand (Pattani, Yala, and Narathiwat provinces).

\section{Methodology}

Preliminarily, the interviewer verbally assessed the information sheet with each respondent, and later described the purpose and the nature of this study. The snowballing sampling method was employed to select 30 transgender respondents, and the semi-structured face-to-face interview sessions were performed to gather data.

The distribution of transgender respondents in this study is as follows: 17 respondents (56.7\%) were 15-19 years old and were studying at secondary school, while 13 respondents (43.3\%) aged from 20 to 25 were pursuing Diploma and Bachelor degree at local higher education institutions.

'Transgender' is a wide-ranging term that includes feminine men, cross-dressers, drag queens, transsexuals, and intersex (Burgess, 1999). In this paper, transgender people refer to those who feel that they have been wrongly considered with their sexual characteristics at child birth. Hence, only transgender women were selected; those with feminine inner feelings and behaving like a woman in their daily life that is against their gender at birth.

\section{Research Instrument}

The snowballing sampling method was employed to select 30 transgender respondents, and the semi-structured face-to-face interview sessions were performed to gather data. 
INTERNATIONAL JOURNAL OF ACADEMIC RESEARCH IN PSYCHOLOGY

Vol. 7, No. 1, 2020, E-ISSN: 2312-1882 @ 2020 KWP

\section{Data Analysis Procedure}

Quantitative data were analysed using Basic Statistics: mean, frequency and percentage. After conducting the interviews, the researcher transcribed into English interview conversations that were in languages other than Thai. The data from interviews, documents, and records were coded and analysed using content and narrative analysis. The results of quantitative and qualitative data analysis were integrated using triangulation.

\section{Ethical Consideration}

All participants in the empirical phase of the case study were selected and later treated with appropriate sensitivity, in recognition of their vulnerability, the sensitivity of the topic of transgenderism, and their close connection with the aim and objectives of the research.

\section{Results}

\section{HIV and AIDS Knowledge Level}

A total of 23 respondents (76.6\%) had awareness on HIV/AIDS, while 7 (23.4\%) were unaware of HIV/AIDS. More interestingly, 26 of the respondents (93\%) were totally unaware of the HIV virus transmission procedure. Next, 17 and 13 respondents (56.7\% \& 43.3\%, respectively) from $15-25$ and 20-25 age groups displayed HIV/AIDS prevalence. Nonetheless, studies conducted by UNFPA and UNICEF revealed several reasons for the transgender community to be lacking in knowledge regarding HIV/AIDS. Oppressive heath frameworks, transphobia, family rejection, as well as pressing need of gaining education and employment, seem to dishearten transgender individuals from seeking services to combat HIV (UNFPA, 2015).

\section{HIV/AIDS Voluntary Counselling and Testing (VCT)}

The number of youths (aged 10-19) living with HIV, which had increased from 1.4 million to 1.8 million between 2007 and 2017, appeared more active than the senior transgender (UNAIDS 'AIDSinfo', 2019). Although countries are progressively counting individuals most influenced by HIV in their national HIV testing rules, such as drug addicts and sex workers; those from the LGBT community seemed to stay restricted in most settings (UNAIDS, 2018).

The HIV testing objectives call for $90 \%$ of all individuals living with HIV to determine their status by 2020, as stipulated in the UNAIDS' 90-90-90 Fast-Track Targets. In 2017, 75\% of all HIV diseases were analysed (UNAIDS, 2017). A rights-based approach that rejects restraint and stigmatisation is basic to effective HIV testing. For this reason, WHO and UNAIDS do not suggest required, obligatory or coerced HIV testing of those on open wellbeing grounds. However, constrained testing of key populations (including detainees and migrants) is practiced in a few countries, including in clinics, particularly in Africa, Asia Pacific, Eastern Europe, and Central Asia (UNAIDS, 2018).

This present study looked into an interesting scenario of Voluntary Counselling Test (VCT) for detecting HIV/AIDS. The noteworthy abnormality of VCT was that 28 respondents (93.3\%) were not tested for HIV/AIDS, while only two respondents had HIV/AIDS examination on annual basis. Next, seven respondents (23.3\%) of the transgender community did use condoms during anal penetration sexual intercourse, whereas five respondents (16.7\%) did not do so while performing sexual activity. A past study discovered that in spite of the fact that there have been numerous campaigns and activities outlined to progress levels of testing, a staggering $43 \%$ of those living with HIV in Thailand 
were unaware of their status (Bhakeecheep, 2014). The open health benefits of HIV testing must continuously exceed the potential harm or risk. The most important reasons for the testing to continue are that it benefits those being tried and to progress the health outcomes at the populace level (WHO, 2016).

Individuals who are most at risk of HIV are failing to get their HIV testing in massive numbers. For instance, between 2010 and 2014, more than 600 million adults from 122 low- and middleincome countries were tested for HIV. As a result, based on the 81 countries that revealed detailed information, fairly $3 \%$ of the tests had been positive (WHO, 2018).

\section{Sexually Transmitted Infection (STI) Testing}

In this present study, 29 respondents had not checked for sexually transmitted infection (STI) since past one year despite having multiple sexual partners due to lack of awareness and apprehension that made them feel stressful. On the contrary, only one respondent had STI check-up and found having STI due to multiple sexual partners. Despite this, the respondents opted for sex worker profession as full-time job while still studying at the local university.

\section{At High Risk Behaviour towards HIV/AIDS and STI Transmission}

\section{Condom Use Practice Knowledge Level of Safe Sex among Respondents}

Interestingly, transmission of HIV virus for high-risk behaviour was linked with the perception of safe sex. Out of the 30 respondents, only 15 (50\%) were knowledgeable about safe sex activity using a condom with an unfamiliar partner, while ten and five respondents (33\% and $17 \%$ ) were unaware and lacked knowledge on safe sexual activity, respectively.

This study offers detailed knowledge on safe sex practices using condoms. A total of 18 respondents $(60 \%)$ used condom for safe sex, while 18 respondents (17\%) did not practice safe sex by not using condom, and five respondents (23.3\%) used condoms occasionally during sexual activity.

\section{Table 1: Reasons for Not Using Condom with Intimate Partner}

\begin{tabular}{llcc}
\hline No. & Reasons for Not Using Condom with Intimate Partner & $\begin{array}{c}\text { Number of } \\
\text { Respondents }\end{array}$ & $\begin{array}{c}\text { Percentage } \\
\text { (\%) }\end{array}$ \\
\hline 1 & Sexual partners feel uncomfortable using condom during & 15 & 50.0 \\
& sex. & 4 & 13.0 \\
2 & Sexual drive is not good. & 10 & 34.0 \\
$3 . \quad$ Not wearing a condom with life partner due to strong & 1 & 3.0 \\
$\quad \begin{array}{l}\text { trust. } \\
\text { 4. } \quad \text { Consuming alcohol and did not realise not wearing a } \\
\quad \text { condom. }\end{array}$ & 30 & 100 \\
\hline
\end{tabular}

This study discovered four significant themes as reasons for dismissing the use of condoms during sexual activity with sexual partner. First, $50 \%$ of the respondents did not use condoms during sexual activity due to dislike or discomfort in using condoms every time performing sexual activity. Second, $14 \%$ of the respondents did not use condoms during sexual activity due to failure of attaining sexual pleasure or sexual superiority. Next, $34 \%$ of the respondents dismissed use of condoms to 
INTERNATIONAL JOURNAL OF ACADEMIC RESEARCH IN PSYCHOLOGY

Vol. 7, No. 1, 2020, E-ISSN: 2312-1882 @ 2020 KWP

display loyalty towards their spouse, so as to indicate that no sexual activity was involved with others. Lastly, only a respondent claimed to have not used condom due to consumption of alcohol.

As a matter of fact, $40 \%$ of the respondents had knowledge on using condoms effectively. The awareness factor was due to the spread of knowledge from close friends with identical transgender personalities. A noteworthy issue highlighted in this study is that $60 \%$ of the respondents were unaware about proper usage of condom, while $90 \%$ of respondents within the 15-19 age group were unaware of using condom properly. The respondents claimed that their desire to have sex was so high that they neglected safe sex by using condom.

\section{Table 2: Level of Knowledge and Understanding the Correct Use of Condom}

\begin{tabular}{llcc}
\hline No. & Knowledge and Correct Use of Condom & $\begin{array}{c}\text { Number of } \\
\text { Respondents }\end{array}$ & $\begin{array}{c}\text { Percentage } \\
\text { (\%) }\end{array}$ \\
\hline 1. & Least knowledge & 5 & 16.7 \\
2. & Average knowledge & 13 & 43.3 \\
3. & Deep knowledge & 12 & 40 \\
\hline & Total & 30 & 100 \\
\hline
\end{tabular}

As for the subject on using condoms the right way, only 12 respondents (40\%) knew the correct way of using condoms after gaining information from close friends with similar transgender identities. It is indeed worrisome that 18 respondents (60\%) did not know the correct way of using condoms, especially those from the 15-19 age group.

Out of the 30 respondents, $75 \%$ had awareness regarding effective condom use learnt from their transgender friends and from working as sex workers outside southern Thailand. A study conducted in 2014 found that use of condoms among transgender individuals across five zones had been $84 \%$. Approximately $59 \%$ of transgender individuals in these zones received anticipation services, and $34 \%$ were tested for HIV. The HIV testing at Chiang Mai city, for instance, had expanded over time, from $22 \%$ in 2005 to $43 \%$ in 2014 (NAC, 2015).

\section{Sexual High Risk Behavior on HIV Transmission}

Interestingly, transmission of HIV virus for high-risk behaviour was also associated with perception of safe sex. The result illustrated that 15 respondents (50\%) were aware of safe sex activity using condom with unfamiliar partner. Meanwhile, 10 respondents (33\%) were unaware of safe sex activity, and five respondents (17\%) lacked knowledge on safe sexual activity.

Upon discussing the respondents' male sexual partners, 23 respondents claimed that their male partners' sexuality status was bisexual due to their sexual relationship with female partners as well. Next, seven respondents mentioned that their sexual partners were gay, as they only had sex with male partners. Five respondents in this study admitted that although they had special male lifepartner, they pursued multiple male sexual partners mainly to fulfil their sexual desire or sexual lust.

In terms of achieving joy in life, all 30 respondents in this study admitted that they had been earning a steady income as sex workers. However, only two respondents (6.7\%) opted for sex worker as their permanent job, while 28 respondents (93.3\%) became sex workers on part-time basis. The main reasons for the respondents to choose sex worker as their profession are: poor family background, as well as need of additional money to cover the cost of everyday living and schooling. Previous research findings explained that an expansive extent of transgender individuals that offered 
INTERNATIONAL JOURNAL OF ACADEMIC RESEARCH IN PSYCHOLOGY

Vol. 7, No. 1, 2020, E-ISSN: 2312-1882 @ 2020 KWP

sex had made them progressively vulnerable to HIV (UNAIDS, 2014). A case study in 2015 conducted by UNICEF reported that $39 \%$ of young transgender individuals participated in sex mainly for income.

\section{Conclusion and Recommendation}

This study had investigated the ineffective condom practice rates, sexual high-risk ratio, and HIV/AIDS prevalence among the transgender population in Southern Thailand (Pattani, Yala, and Narathiwat provinces). As a conclusion, it was found that although most of the respondents did reckon the dangers posed by HIV/AIDS, they were uncertain about the transmission of HIV virus. Most of them failed to get tested in order to determine their HIV/AIDS status. A majority of the respondents were unaware about the significance of safe sex using condoms. Therefore, both the government and non-governmental agencies should put in more effort to enhance awareness pertaining to effective use of condoms and the importance of safe sex amongst the transgender community to curb HIV/AIDS.

Through this research, the government and the local community will have a better understanding towards the psychosocial aspects of young transgender who faced various challenges especially facing stigma and discrimination by the local society in Pattani, Yala and Narathiwat, Thailand who are majority living in Islam faith.

At the same time, this research can contribute to the National Strategic Plan for HIV / AIDS in Thailand provides additional information about the pattern of sexual behaviour young transgender in Pattani, Thailand, particularly the challenges faced by transgender people in their Muslim communities who are against the movements of LGBT. This research is very useful to social workers in Thailand to gain more psychosocial aspects experienced by transgender people and can providing more effective interventions for this marginalized populations.

\section{Conflict of interest}

The authors have no potential conflict of interest to declare.

\section{Acknowledgement}

The authors would like to thank the Prince of Songkla University, Pattani campus, Thailand for their support in providing the necessary facilities to produce this paper.

\section{Funding}

This research was supported by Faculty of Humanities and Social Sciences, Prince of Songkla University, Pattani Campus, Thailand.

\section{References}

APTN / UNDP. (2012) 'Lost in Transition: Transgender People, Rights and HIV Vulnerability in the Asia-Pacific Region'. Retrieved from https://www.undp.org/content/dam/undp/library/hivaids/Lost\%20in\%20translation.pdf.

Bekker, L. G., Johnson, L., Wallace, M., and Hosek, S. (2015). Building our youth for the future. Journal of the International AIDS Society, 18 (2 Suppl 1): 20076. DOI: 10.7448/ IAS.18.2.20027. http://www.jiasociety.org/index.php/jias/ article/view/20027/html (Accessed 24 August 2017).

Burgess, C. (1999). Internal and external stress factors associated with the identity development of transgendered youth. In G. Mallon (Ed.), Social services with 
INTERNATIONAL JOURNAL OF ACADEMIC RESEARCH IN PSYCHOLOGY

Vol. 7, No. 1, 2020, E-ISSN: 2312-1882 @ 2020 KWP

transgendered youth (pp. 35-47). New York: Harrington Park Press.

Chemnasiri, T., Netwong, T., Visarutratana, S., Varangrat, A., Li, A., Phanuphak, P., Jommaroeng, R., Akarasewi, P., and Van Griensven, F. (2010). Inconsistent condom use among young men who have sex with men, male sex workers, and transgenders in Thailand. AIDS Education and Prevention, 22(2),100-109.

Musheke, M., Ntalasha, H., Gari, S., McKenzie, O., Bond, V., Martin-Hilber, A., Merten, S. (2013). A systematic review of qualitative findings on factors enabling and deterring uptake of HIV testing in Sub-Saharan Africa', BMC Public Health. 2013; Volume 13, Issue 220.

MSMGF. (2015) 'Rights in Action: Access to HIV Services among Men Who Have Sex with Men'. Retried from https://mpactglobal.org/rights-action-access-hiv-services-among-mensex-men/.

NAC. (2015) 'Thailand AIDS Response Progress Report 2015. Retried from https://www.unaids.org/sites/default/files/country/documents/THA_narrative_report_201 5.pdf.

Operario, D., Nemoto, T., Iwamoto, M., Moore, T. (2011). Unprotected sexual behaviour and HIV risk in the context of primary partnerships for transgender women. AIDS Behaviour. 2011; 15(3):674-82.

Salazar, L. F., Crosby, R. A., Jones, J., Kota, K., Hill, B., Masyn, K. E. (2017). Contextual, experiential, and behavioral risk factors associated with HIV status: a descriptive analysis of transgender women residing in Atlanta, Georgia. International Journal STD AIDS. 2017 956462416686722.

UNICEF. (2015). 'Situational analysis of young people at high risk of HIV exposure in Thailand'. Retried from https://www.unicef.org/thailand/UNICEF_study_on_HIV_infection_among_young_peole_FI NAL_ENGLISH.pdf.

UNDP, USAID. (2014). Being LGBT in Asia: Thailand Country Report. Bangkok.

United Nations Educational, Scientific and Cultural Organization, United Nations Population Fund, Joint United Nations Programme on HIV/AIDS, United Nations Development Programme. Young people and the law in Asia and the Pacific: A review of laws and policies affecting young people's access to sexual and reproductive health and HIV services. Bangkok: United Nations Educational, Scientific and Cultural Organization; 2013 (http://unesdoc.unesco.org/images/0022/002247/224782e.pdf, accessed 16 June 2014).

United Nation. (2015). Transforming our world: The 2030 agenda for sustainable development. Retrieved from https://sustainabledevelopment.un.org/content/documents/21252030\%20Agenda\%20for\% 20Sustainable\%20Development\%20web.pdf.

UNAIDS. (2014). 'The Gap Report. Retried from http://files.unaids.org/en/media/unaids/contentassets/documents/unaidspublication/2014 /UNAIDS Gap report en.pdf.

WHO. (2016). 'Supplement guidelines on HIV self-testing and partner notification: supplement to consolidated guidelines on HIV testing services'. Retried from https://www.who.int/hiv/pub/vct/hiv-self-testing-guidelines/en/.

UNAIDS. (2017). 'Blind spot: addressing a blind spot in the response to HIV. Reaching out to men and boys. Retried from https://www.unaids.org/sites/default/files/media_asset/blind_spot_en.pdf. 
INTERNATIONAL JOURNAL OF ACADEMIC RESEARCH IN PSYCHOLOGY

Vol. 7, No. 1, 2020, E-ISSN: 2312-1882 @ 2020 KWP

UNAIDS. (2018). 'Miles to go: global AIDS update 2018'. Retried from

https://www.unaids.org/sites/default/files/media_asset/miles-to-go_en.pdf.

UNAIDS 'AIDSinfo'. (2019). Retried from http://aidsinfo.unaids.org/.

UNFPA. (2015) 'Technical brief: HIV and young transgender people. Retried from https://www.unfpa.org/sites/default/files/pub-pdf/WHO_HIV_2015.9_eng.pdf.

WHO, UNAIDS. (2018). HIV self-testing africa initiative (2018) 'Knowing your status - then and now'. Retried from https://www.who.int/hiv/pub/vct/who-unitaid-know-your-hivstatus/en/. 